\title{
Regulation, governance and the role of the informal sector in influencing environmental quality?
}

Article

Accepted Version

Creative Commons: Attribution-Noncommercial-No Derivative Works 4.0

Bali Swain, R., Kambhampati, U. and Karimu, A. (2020) Regulation, governance and the role of the informal sector in influencing environmental quality? Ecological Economics, 173. 106649. ISSN 0921-8009 doi:

https://doi.org/10.1016/j.ecolecon.2020.106649 Available at https://centaur.reading.ac.uk/89332/

It is advisable to refer to the publisher's version if you intend to cite from the work. See Guidance on citing.

To link to this article DOI: http://dx.doi.org/10.1016/j.ecolecon.2020.106649

Publisher: Elsevier

All outputs in CentAUR are protected by Intellectual Property Rights law, including copyright law. Copyright and IPR is retained by the creators or other copyright holders. Terms and conditions for use of this material are defined in the End User Agreement.

www.reading.ac.uk/centaur 
Central Archive at the University of Reading

Reading's research outputs online 


\title{
Regulation, Governance and the Role of the Informal Sector in Influencing Environmental Quality?
}

\begin{abstract}
We investigate the effect of the informal sector and a range of governance indicators on both global and local pollutants for a panel of 58 countries during 1996-2011. The analysis employs a fixed effects-instrumental variable generalized method of moments approach. We find that the size of the informal sector has a significant impact on environmental quality, which is conditional on the level of economic development. For developing countries, the informal sector has a significant positive impact on local pollutants, whereas for the developed countries the informal sector has a significantly negative effect on global pollutants. The findings also reveal that the impact of governance depends on the type of governance measure, the level of economic development and type of pollutant. Control of corruption emerges as the single most important factor especially in the non-OECD countries in improving environmental quality. We argue that the efficacy of an environmental policy for a country with a large informal sector will be low if the policy measures do not address governance, size of the informal sector and environmental policy targets.
\end{abstract}

Keywords: Environmental quality, Informal Sector, Governance

JEL Classification: O17, 043, Q53, Q56, Q58 


\section{Introduction}

Much of the existing literature on the determinants of environmental quality is framed within the Environmental Kuznets Curve (EKC) framework. ${ }^{1}$ While the EKC itself is a stripped-down inverted- U relationship between various indicators of environmental quality and economic growth, recent work has extended the model to include wider determinants of environmental quality. Empirical estimation of the EKC has recognised that in a reduced form model, income acts as a proxy for too many other determinants (for instance, level of economic activity, structure of the economy, regulatory capability etc.), thus leading to an omitted variable(s) bias. This recognition led to attempts to extend the model by including variables relating to the structure of the economy, energy prices, trade openness and occasionally political rights and civil liberties.

In this paper, we analyse the impact of regulation and governance (or more precisely, lack of regulation and governance) and the informal sector on environmental quality. To date, most studies that have analysed the impact of institutions have concentrated on political rights and civil liberties (Congleton, 1992; Farzin and Bond, 2006; Bernauer and Koubi, 2009; You et al., 2015). We argue that political rights and civil liberties variables themselves are reduced form versions of variables like regulatory quality, voice and accountability and the rule of law that are more appropriate in this context. In this paper therefore, we consider the impact of regulation from two angles. First, we include the size of the informal sector as a proxy for the level of regulation and governance that an economy experiences. The larger the informal sector, the less regulated is the economic activity in the economy. It is worth caveating this contention by acknowledging that the informal sector is likely to operate under a range of non-state norms and conventions which will influence behavior and yield accountability. These conventions and norms are likely to vary across countries and communities. However, for the purposes of the analysis in this paper, our concern is with the impact that formal rules and regulations imposed by the state may have on economic activity and environmental quality. Our second measure of regulation and governance therefore relates to more direct measures of such governance - control of corruption, political stability, government effectiveness and voice and accountability. The informal sector is, by definition, the sector with a minimum of formal regulations and governance. The 15th

\footnotetext{
${ }^{1}$ Kuznets (1955) hypothesized that during the earlier stages of economic growth income inequality increases while declining in the later stages of development. This gave an inverted U-shaped relationship between the income per capita and income inequality. A similar inverted U-shaped relationship was believed to exist between the income per capita and the environmental degradation and was termed the Environmental Kuznets Curve by Panayotou (1993). Grossman and Krueger (1991), Shafik and Bandyopadhyay (1992) and Panatayou (1993) were amongst the first set of empirical EKC studies.
} 
International Conference of Labour Statisticians (in 1993) at the International Labour Organisation (ILO), defined the informal sector as a group of production units comprised of unincorporated enterprises that are owned by households, including informal own-account enterprises and the enterprises of informal employers. These may include street vendors, manufacturing and repair sweat shops etc. If the informal sector has a positive impact on emissions, then we might conclude that the lack of government regulation allows this sector to pollute more than the formal sector. Also, it is possible that the lack of regulation or the avoidance of existing regulation (through, for instance, outsourcing) causes the activities to shift from the formal (more regulated) sector to the informal (less regulated) sector.

It is clear that there are many kinds of pollutants, which vary in their sources, their dispersion as well as their impact. Thus, some pollutants are related only to agriculture, while others are related to the use of carbon-fuel in industry. Pollutants can be local or global. Some pollutants have a very long lifetime in the environment while others are more short-lived. We therefore analyse the emissions of a range of pollutants including carbon-dioxide $\left(\mathrm{CO}_{2}\right)$ per capita, $\mathrm{CO}_{2}$ per unit of energy use (carbon intensity), organic and chemical water pollutants per worker and the ecological footprint bringing together data from the UN Environment Programme, the World Bank (2012) and Schneider et al. (2010).

This study makes several contributions to the literature. First, while many papers [Farzin and Bond (2006); Torras and Boyce (1998)] have looked at the impact of political rights and civil liberties on environmental quality, they have concentrated on broad democracy and other political rights indicators. They have also tended to create a single index (Bhattarai and Hammig, 2001), which has meant that they are unable to identify which aspects of regulation and governance are most crucial to environmental quality. Using data made available by the World Bank (2012) on governance across countries, we are able to investigate the impact of specific aspects of governance on decreasing emissions. Second, the paper systematically analyses the role of the informal sector in influencing environmental quality. The few studies that consider the impact of informal economic activity on local pollutants rely on specific case studies and concentrate on local pollutants. Research on the wider environmental impact of the informal sector (both geographically as well as across a range of pollutants) is very limited. Analysing the impact both of the informal sector as well as governance allows us to comprehensively consider the role that lack of governance plays in environmental problems. Finally, we test a range of methodologies (appropriate for panel data), which correct for endogeneity as well as cross-country 
heterogeneities, problems that are common in analyses of environmental quality. Key findings from our study indicate that, in general the informal sector positively influences the emission of local pollutants but has no impact on global pollutants such as $\mathrm{CO}_{2}$ per capita and $\mathrm{CO}_{2}$ intensity in our sample of 58 Countries. Moreover, the effect of the informal sector also depends on the level of development. It is associated with lower global emissions for developed countries though it has no significant effect on global pollutants in developing countries. The study also finds that the control of corruption and political stability are highly significant governance measures in determining environmental quality in developing countries.

In what follows, we will review the literature before moving on to discuss the data and methodology in Section 3 and the results in Section 4. The summary and conclusions are discussed in the final section.

\section{Literature Review}

A large proportion of the literature on environmental quality is embedded within the $\mathrm{EKC}$ framework (Grossman and Krueger, 1991, 1995; Shafik and Bandyopadhyay, 1992; World Bank, 1992; Panatayou, 1993; see Dinda, 2004 for a survey). ${ }^{2}$ This is not surprising because the EKC provides a convenient and easy to use framework with an intuitive foundation - the relationship between economic activity and environmental quality. This has become especially important in recent years due to the concerns relating to increasing global pollution levels while at the same time there is an acceptance of the need to reduce global poverty via accelerated economic growth. Based on various assumptions the EKC relationship between environmental quality and income can be obtained theoretically (John and Pecchenino, 1994; Selden and Song, 1995; Stokey, 1998; Dinda and Coondoo, 2002). The EKC can be derived from the technological link between consumption of a desired good and abatement of the 'bad' produced as a by-product (Andreoni and Levinson, 2001) or the marginal cost and marginal benefit (Munasinghe, 1999). Lopez (1994) argues that income growth is driven by the accumulation of production factors, which also lead to an increase in firms' demand for polluting inputs. At the same time, this income growth leads to an increase in the demand for environmental quality as well as an increase in the willingness to pay for a clean environment increases.

\footnotetext{
${ }^{2}$ Some researchers argue that increase in environmental deterioration is transient and with greater economic growth, environmental quality will improve (Beckerman, 1992; Bhagwati, 1993; Barlett, 1994; Lomborg, 2001). Others insist that trade liberalization re-distributes pollution from rich countries to poor countries, as the pollution-intensive industries move to developing countries (Suri and Chapman, 1998; Ekins 1997). Arrow et al., 1995 believe that economic growth is neithera necessary nora sufficient factor to induce environmental improvement.
} 
Despite having spawned a large literature, the framework has been criticised because its reducedform implies that there is a potential for bias arising from variables omitted from the model (Galeotti et al., 2009) and also because the model does not provide much policy-relevant information. Thus, for instance, what is one to conclude if emissions from a particular pollutant have an inverted-U shape? We can derive the turning point but only for the sample of countries in that study. We cannot generalise from this sample to all countries, in particular because there is a range of variables that could help to shift the EKC and therefore its turning point.

EKC empirical studies have recognised that in such a reduced form model, income proxies for several other determinants, for example, the level of economic activity, structure of the economy, regulatory capability as well as incentives (Stern 2004, 2007; Dijkgraaf and Vollebergh, 1998, 2005; Holtz-Eakin and Selden and Song, 1995; Richmond and Kaufmann, 2006; MullerFurstenberger and Wagner, 2007; He, 2007; Hossain, 2011). In recent years, therefore, more attention has been paid to factors (other than income) which influence pollutant emissions. These include the structure of the economy, energy prices, trade openness and occasionally political rights and civil liberties (Dasgupta and Maler, 1995; Barrett, 2000; Barrett and Graddy, 2000; Harbaugh et al., 2002; Narayan and Narayan, 2010). Several studies emphasise that formal and informal regulations and enforcement improve environmental quality (Pargal and Wheeler, 1996; Panayotou, 1999; Hettige et al., 2000; Dasgupta et al., 2002). In particular, Dasgupta et al., (1995) argue that waiting for the turning point in the EKC to deliver better environmental results is foolish. It assumes that incentives and regulations only change when income increases. However, it is possible for direct action to improve regulations and therefore hasten the EKC turning point. To test this, Dasgupta et al., (1995) use the World Bank's Country Policy and Institutional Assessment for Environment (CPIAE) data. They find that poor governance and geographical vulnerability account for very high levels of pollution in many developing country cities and therefore conclude that policy reform is necessary to improve environmental quality in these countries. Barrett (2000) finds that an increase in civil and political freedoms decreases some pollutants (including suspended particulates). This finding is also confirmed by Harbaugh, Levinson and Wilson (2000) who find a significantly negative association between suspended particulates in the air and a measure of democratic participation.

Leitao (2010) analyses the impact of corruption on sulphur emissions using data from the International Country Risk Guide for corruption. He concludes that corruption shifts the turning point of the $\mathrm{EKC}$ to the right i.e. prevents emissions from decreasing earlier. Farzin and Bond 
(2006) find that democracy and its associated freedoms provide the conduit through which agents can exercise their preferences for improved environmental quality. These results confirm those from earlier studies that greater political rights and civil liberties would improve environmental quality (Torras and Boyce, 1998) or that secure property rights and better enforcement of contracts help flatten out the EKC and decrease the environmental cost of economic growth (Panayatou, 1997). Bhattarai and Hammig (2001) using an index of 12 political rights and 7 civil liberties find that better institutions decrease de-forestation in Africa and Latin America but not in Asia.

Beyond the EKC framework, there are theories proposed to directly and formally provide the dynamics of the economic growth-environmental quality relationship. The formal standard theoretical literature that makes attempts to provide mechanisms relating to the relationship between economic growth and pollution dynamics is the work by Keeler et al., (1971). In his model, the focus was on the interaction between capital accumulation and emission intensities (Brännlund et al., 2017). The link between output growth and environmental quality in their model is through an emission function ${ }^{3}$, which was further developed by theoretical models (Van der Ploeg and Withagen,1991; Bovenberg and Smulders, 1995; Stockey, 1998). These models did not incorporate abatement directly and therefore were unable to comment on the direct pollution reduction mechanisms. Later models such as those developed by Brock and Taylor (2005, 2010) and Ordás Criado et al. (2011) incorporated abatement directly into the emission function to provide a theory with more policy relevant outcomes. The model developed by Brock and Taylor is based on the neoclassical Solow growth model, but extends it by incorporating pollution abatement via the emission function. The authors assumed that both the abatement and savings rates are exogenously determined. Their model indicates that growth in emissions depends on the initial level of emissions, saving rate, abatement intensity, population growth rate and the depreciation rate. On the other hand, in a Ramsey type endogenous growth model, Ordás Criado et al. (2011) relaxed the exogeneity of saving and abatement rates in Brock and Taylor and endogenised the propensity to consume and invest in clean technologies. In developing the model, the authors use a similar emission function to Brock and Taylor and assume that the individual's utility function is affected by consumption per capita as well as pollution per capita. As the above indicates, a range of studies has empiricised the EKC and extended the basic model. Some researchers have also analysed the impact of political rights and civil liberties indices on

\footnotetext{
${ }^{3}$ The emission function assumes that productive processes generate pollution, and pollution is assumed to depend on output(i.e., the production process).
} 
various measures of environmental quality. However, few (if any) of these studies have looked separately at the specific aspects of regulation and governance that are most effective in decreasing emissions or improving environmental quality. This is crucial if we are to draw policyrelevant conclusions from our analyses. This is what we turn to in this paper.

\section{Data and Methodology}

\subsection{Data}

Our analyses are based on data from 58 countries for 16 years (1996-2011). The data has been brought together from a number of sources. Data on environmental quality is from the Geo database of the UNEP (the UN Environmental Data Explorer). In addition, we have data on GDP and other economic variables from the World Development Indicators of the World Bank (2012) and the governance indicators are from the Worldwide Governance Indicators. This provides data for 201 countries in the world on several governance indicators including control of corruption, political stability, government effectiveness and voice and accountability. We use these indicators separately as there is significant variability within country across these indicators. In India, for instance, in 2011, the index for political stability was very low at -1.2 while that for voice and accountability was relatively high at +0.41 , suggesting that the performance of countries across these indicators need not be uniform. Since each of these indicators could have very different impats on environmental quality, it is appropriate to analyse their impacts separately. Finally, we obtain data on levels of informality from Schneider et al. (2010) which is available on the World Bank website. We will discuss these variables later in the paper.

\subsection{Model and tests}

The model empirically tested for each of the dependent variables $Y_{\text {it }}$ is as follows:

$$
Y_{i t}=X_{i t}^{\prime} \beta+\left(\alpha+u_{i}\right)+\varepsilon_{i t}
$$

where, $\alpha$ is the mean of unobserved heterogeneity, $\mathrm{u}_{\mathrm{i}}$ is heterogeneity specific to country $\mathrm{i}, \varepsilon_{\mathrm{it}}$ is the remaining country-year heterogeneity, $\mathrm{Y}_{\mathrm{it}}$ is the environmental quality variable, and $\mathrm{X}_{\mathrm{it}}$ and $\beta$ are the matrix of explanatory variables (including log GDP per capita, sectoral characteristics, governance, informality of the economy etc., which are discussed later in this section) and the vector of coefficients respectively. 
We estimate our model using the fixed effects instrumental variables (IV-FE) ${ }^{4}$ approach based on Schaffer (2012). In the fixed-effects estimations, individual country averages are subtracted from the annual observations and regressions on these transformed variables are performed. Thus, we control for individual country heterogeneities, as fixed effects are assumed constant throughout the observation period.

Most studies of emissions of this kind face endogeneity problems. This endogeneity might arise both from reverse causality between environmental quality and GDP and also because of omitted variables in the model estimated. While GDP can be expected to influence emissions directly, there is the possibility (especially over time) that emissions will also influence GDP. In fact, an assumption that GDP is exogenous implies that we are assuming that the GDP level is fully sustainable. This is clearly not true for most countries, which are trying to improve the quality of their environment often through changes in the structure of their GDP or its size.

We begin by testing for endogeneity using the Durbin-Wu-Hausman (DWH) method and find that there is significant endogeneity in the model. To correct for this endogeneity, we need to instrument GDP in order to identify its coefficient. We use the age dependency ratio and its lags as instruments for GDP ${ }^{5}$. The age dependency ratio is correlated with GDP but does not have a direct effect on the dependent variable (environmental quality). The age dependency ratio is the ratio of dependents - people younger than 15 or older than 64 to the working age population (ages 15-64) (World Bank 2012). It therefore captures the population that does not participate fully in the labour market. The larger the proportion of the population in this age group, the lower will be both the level of GDP and its growth. If the dependency ratio was weighted towards the younger age group, one would expect the country to experience high growth rates in the future due to the demographic transition of the young age group into an active labour force. This has been seen from the very high rates of growth (and significant improvement in the level of GDP) by some emerging economies like China and India and the other BRIC economies, which have been argued as having high potential for growth because they have young, working age populations ${ }^{6}$.

\footnotetext{
${ }^{4}$ Additional estimations were also performed with fixed-effects instrumental variable with lagged explanatory variables and limited information maximum likelihood (LIML) estimation methods and gave similar results.

${ }^{5}$ We follow Lin Lawell and Liscow, 2013 regarding the use of age dependency ratio as an instrument for GDP, but unlike them, we did not include debt service ratio as a valid instrument. The reason being that in our sample, debt service ratio is not highly correlated with GDP (-0.0169). More importantly, the correlation is statistically insignificant at any of the conversional significance level.

${ }^{6}$ Recentevidence suggests that declining youth dependency ratios in developing countries can contribute to the economic growth, likeitdidincountrieslikeEastAsia(Bloometal.2001;Bloometal.,2003).
} 
It is therefore expected that the age dependency ratio variable will be strongly correlated with both GDP growth and its level but uncorrelated with emissions. To test the exogeneity of the instruments, we use Hansen's (1982) J-test. Our results indicate that the instrument is exogenous and therefore a good instrument for GDP.

The above instrument (age dependency ratio) is employed to estimate the fixed effects-IV models, which help to correct not only for endogeneity but also for unobserved cross-country heterogeneities via the country fixed effects. In particular, it is clear that some countries are geographically or climatically constrained to using more energy or possibly to higher levels of emissions. Country fixed effects will help to capture these heterogeneities while time fixed effects will help to capture improvements due to technological changes or sudden weather shocks. Baltagi (2005) and Hahn and Whitney (2004) suggest that IV estimations can take care of the potential problems associated with outliers with bad leverage and weak instruments in unbalanced panel data.

\subsection{Variables}

As indicated earlier, our model includes log GDP per capita as a measure of economic growth. We also include two variables relating to the structure of the economy - agriculture value added and industry value added. It might be expected that a high proportion of GDP being derived from agriculture will lead to different environmental emissions than when industry predominates. $\mathrm{CO}_{2}$ emissions, for instance, are likely to be higher in industrial countries due to the high capitalintensive industrial sectors of such countries relative to developing countries. In general, high capital-intensive sectors tend to depend heavily on fossil fuels, a key contributor to carbon emission. In what follows, we will discuss our variables of interest in more detail.

Environmental quality and emission variables: We analyse a range of environmental quality variables including Carbon Dioxide per capita as well as Carbon Dioxide per unit of energy use (carbon intensity), water pollution per worker and ecological footprints.

Carbon-dioxide: is a primary greenhouse gas emitted through human activity. It is caused mainly by the combustion of fossil fuels (coal, oil and natural gas) for energy and transportation. Though it is part of the earth's natural carbon cycle, we are currently emitting too much $\mathrm{CO}_{2}$, which is maintained in the atmosphere for 50-200 years and causes global warming (United States 
Environmental Protection Agency, 2017). $\mathrm{CO}_{2}$ per capita allows for the fact that larger countries with large populations will have higher emissions than smaller countries simply by virtue of their size. $\mathrm{CO}_{2}$ /energy, on the other hand, is a measure of the emission intensity in terms of carbon emission per unit of energy used. This is likely to depend on the structure of production as well as on how efficient and clean the production processes in the economy are.

Water Pollution per worker: is the total emission of organic water pollutants, which is divided by the number of industrial workers. Organic water pollutants are measured by biochemical oxygen demand, which refers to the amount of oxygen that bacteria in water will consume.

Water Pollution (Chemical): arises from metals and solvents from industrial work, from pesticides and fertilizers used in agriculture and from petroleum spillages. Given the nature of the pollutants and the emissions, it is likely to be more local than $\mathrm{CO}_{2}$ or $\mathrm{NO}_{2}$ emissions, for instance.

Ecological footprint: The Ecological Footprint is a measure of the consumption of renewable natural resources by a human population, be it that of a country, a region or the whole world. A population's ecological footprint is the total area of productive land or sea required to produce.

Informal Economy: We analyse the role of regulation in governance by considering both the impact that the informal economy has on emissions as well as the impact of specific governance indicators. The International Labour Organisation defines the 'informal economy' as all economic activities by workers and economic units that are - in law or in practice - not covered or insufficiently covered by formal arrangements"7. In this paper, we use the data provided by Schneider et al. (2010) as a measure of the informal economy. This measure includes all marketbased legal production of goods and services that are deliberately concealed from public authorities to avoid payment of income, value added or other taxes; payment of social security contributions; compliance with certain legal labor market standards, such as minimum wages, maximum working hours, safety standards, etc.; and compliance with certain administrative procedures, such as completing statistical questionnaires or administrative forms. Based on this definition, they calculate a measure of the informal economy for 162 countries for the years 1999-

\footnotetext{
7 Their activities are not included in the law, which means that they are operating outside the formal reach of the law; or they are not covered in practice, which means that-although they are operating within the formal reach of the law, the law is not applied or not enforced; or the law discourages compliance because it is inappropriate, burdensome, or imposes excessive costs."
} 
2006. They allow for a number of indicators of the informal economy including intensity of regulations (which also includes regulatory quality from the World Governance Indicators), public sector services (including government effectiveness from the Worldwide Governance Indicators), GDP, unemployment rate, openness, tax and social security burdens, labour market indicators as well as the use of cash in the economy as opposed to bank accounts etc. These measures are then brought together using a Multiple Indicators Multiple Causes (MIMIC) methodology to construct the informal variable (indicator) (Schneider et al, 2010).

Governance Variables: In addition to the broad informal economy variable discussed above, we also estimate our model separately with four governance indicators from the Worldwide Governance Indicators data created by Kaufman et al., (2010). These variables range from -2.5 (weak governance) to +2.5 (strong).

Voice and Accountability: reflects the perceptions of the extent to which a country's citizens are able to participate in selecting their government as well as freedom of expression, freedom of association and a free media. We might expect that the stronger this is, the lower will be emissions because there is room for public opinion to influence and constrain the actions of big business, industry and policy maker, given that the consequences of the emissions are directly felt by the population. The importance of this indicator is being felt everyday by the impact that individuals like Greta Thunberg or interest groups like Extinction Rebellion have had on economic agents as well as government policy. However, much will depend upon the public opinion itself. It is entirely possible that public opinion is skewed in favour of increased economic activity whatever the cost to the environment. Having said this, it seems likely that high levels of voice and accountability enable a range of opinions to be expressed and therefore are less likely to simply lead to increased emissions.

Government effectiveness: is the quality and competence of public services and civil service provision, independence from political pressures, the quality of policy formulation and implementation, and the credibility of the government in implementing formulated policies.

Political Stability/No Violence: reflects perceptions of the likelihood that the government will be destabilised or overthrown by unconstitutional or violent means, including political terrorism and violence. Again, it ranges between $+/-2.5$. It is unclear how this will work. Countries which are experiencing conflict or political violence are unlikely to be able to legislate in favour of 
environmental quality or to enforce the regulations that already exist. They are also unlikely to protect common property or invest in common resources as various groups in the conflict vie for larger shares in these resources.

Control of Corruption: reflects the extent to which public power is exercised for private gain, including both petty and grand forms of corruption as well as 'capture' of the state by elites and private interests. This could allow rents to be captured by strong private agents and much less likelihood of the social costs of production being reflected either in the prices or the tax regimes. Other variables included in our analysis are energy use per capita, which is total energy use as a ratio of the population, trade i.e. exports plus imports expressed as a ratio of GDP, and the age dependency ratio.

Table 1 presents the descriptive statistics of the main variables used in the analysis and shows that on average nearly one-third (32.6 percent) of the economy is in the informal sector. Moreover, the descriptive statistics indicate a significant variability in the key variables across the countries in the data set as depicted by the standard deviation values.

$<$ Table 1 about here $>$

\section{Results}

We begin by estimating the reduced form model of the impact of the informal economy on the emission of pollutants, after controlling for log GDP per capita. In all estimations, we log transformed all the variables before estimation for two reasons. First, the log transformation helps to reduce outlier effects. And second, it makes it easy to achieve normality of the random error term of our IV-fixed effect model. Note that all the governance indicators range from -2.5 to +2.5 and therefore in order to apply the log transformation, we rescaled them to be positive. Our analysis follows three steps. First, we estimate the reduced-form model as presented in equation (1), where we focus on the role of the informal sector on the five different pollutants in our dataset. Next, we estimate a reduced form model as presented in equation (1), but we replace the informal sector variable with four different governance indicators, to assess the effect of each governance indicator on each of the five pollutants. In the final step, we divide our sample into two sub-samples - the OCED and the non-OECD countries. Given that these groups of countries 
are at different levels of development, we might expect their economic structure and institutions to be significantly different from each other. Separating out the sub-samples allows us to consider if there is a discontinuity in the slope of the relationship across these groups of countries.

The results for the first step are presented in Table 2 and show that the larger is the informal economy, the higher are local pollutants (water-pollutants per worker, water-pollutants per chemical and the ecological footprint). However, the informal sector has no significant effect on global pollutants such as carbon emission per capita and carbon intensity. This is consistent with the finding by Hettige et al. (1996), where plants located in urban/industrial clusters that operated invisibly had a negative impact on pollution abatement. This is not surprising, given that across large parts of the world, the informal economy is seen to encourage the use of wood fuels and farming practices that lead to the reduction in the ecological footprint. Economies with a larger informal sector also tend to contribute more to water pollution because activities from the informal sector are not easy to track and regulate. Informal mining activities, for instance, where various chemicals are used to wash the minerals and the wastewater is dumped into rivers and other water bodies contribute to water pollution. Finally, our results above indicate that, after controlling for GDP per capita, the informal economy significantly increases the organic water pollutants per industrial worker and water pollution from chemicals. Again, this result is not surprising because organic and chemical water pollutants are likely to be more common and less regulated in the informal and relatively small-scale sectors (Hettige et al., 1996). Their impact on water pollution is therefore likely to be more obvious than their impact on air quality, which is a global 'bad'.

The informal sector also leads to a greater demand on the Ecological Footprint (which gauges the total area of productive land or sea required to produce). Our results for the informal sector are reinforced by the fact that $\mathrm{CO}_{2}$ emissions are higher in urban economies and in economies with a higher use of energy resources.

$<$ Table 2 about here $>$

It is also important to note that, controls such as urbanization have a positive effect on global pollutants such as $\mathrm{CO}_{2}$ per capita emission and $\mathrm{CO}_{2}$ intensity, which is consistent with the finding by Biswas et al., (2012). Urbanisation, however, has a negative effect on local pollutants, where the negative effect is statistically significant for both chemical water pollution and the ecological 
footprint, with elasticity values of -0.98 and -0.68 , respectively. GDP per capita has a positive effect on all pollutants, with the effect being significant in the case of $\mathrm{CO}_{2}$ per capita, chemical water pollutants and the ecological footprint.

Furthermore, it is useful to consider why one might expect the informal economy to influence the level of pollution. This might happen for a number of reasons. First, a large informal sector might skew the structure of the economy in the direction of certain sectors (e.g. services) that are more likely to be informal (and less likely to pollute). If this were the case, we might expect the informal economy to have a negative impact on pollution. Second, the informal sector may use different types of fuel or less fuel than the formal sector. If the former, then it is likely to contribute to increased pollution but if the latter, then it may actually decrease pollution. There are a number of studies that argue that the use of wood fired kilns in the informal sector actually increases the pollution contribution of this sector rather than reduces it. Finally, the informal sector is so termed because it is less regulated than the formal sector. This implies that its activities face fewer constraints in terms of legislation against pollution, taxes to reduce pollution etc. and in this case we might expect it to have an increased impact on pollution. Note that while the first and third factors would influence both air and water pollution, the second factor is only likely to be significant for air pollution.

In the reduced form version of the model that we consider in Table 2 (also see appendix), we are unable to separate out these effects. As a consequence, in the second step, we re-estimate the model, in particular including a range of governance variables, which helps us determine whether the effect of the informal sector relates to the lack of governance associated with it or to some other factors. The variables we include are control of corruption, political stability, government effectiveness and voice and accountability. The results based on the second step estimation are presented in Table 3.

Our results indicate that, for $\mathrm{CO}_{2}$ emissions per capita, the higher is GDP per capita, the higher is the per capita $\mathrm{CO}_{2}$ emissions. This is typical of the scale effect which asserts that growing economic activity leads to increased environmental damage as more resources are required for increasing production (Brock and Taylor, 2005). Thus, the more prosperous an economy, the higher is its $\mathrm{CO}_{2}$ emissions per capita. This finding is consistent with previous literature (Biswas et al., 2012; Gani, 2012; Elgin and Oztunali, 2014). We control for both industry value added and urbanization and therefore the coefficient of GDP per capita is conditional on these. This 
positive effect of GDP per capita is consistent for all pollutants, it is however insignificant in the case of water pollutants.

Amongst the governance variables, we find control of corruption to have a negative significant effect on four of the five pollutants. It is insignificant only in the case of ecological footprint. This confirms that among other things, the control of corruption reduces $\mathrm{CO}_{2}$ per capita, organic and chemical water-pollutants per worker. Thus, after controlling for level of GDP per capita, an economy with lower corruption (fewer irregular payments, less public funds diverted, more trust in politicians etc.) has lower $\mathrm{CO}_{2}$ pollution as well as water pollution. This finding is in line with Brännlund et al., (2015), where they find a negative effect of corruption on $\mathrm{CO}_{2}$ per capita emission for a global sample. Also, Gani (2012) found a negative effect of control of corruption on both $\mathrm{CO}_{2}$ per capita emission and $\mathrm{CO}_{2}$ intensity amongst developing countries.

The results also indicate that political stability has a positive effect on global pollutants, but a negative effect on local pollutants. Specifically, it increases $\mathrm{CO}_{2}$ per capita and $\mathrm{CO}_{2}$ intensity (contrary to the finding in Gani, 2012), whereas it decreases chemical water pollutants and the ecological footprint. This might relate to the fact that economies that are more politically stable have better established manufacturing sectors, which will increase the $\mathrm{CO}_{2}$ emissions. It will decrease chemical water pollution because in such economies it is easier enforce regulations. The difference in our findings for $\mathrm{CO}_{2}$ per capita and $\mathrm{CO}_{2}$ intensity, as compared to Gani (2012), may be due to the fact that we considered both the developed and the developing countries. Gani, on the other hand focused only on developing countries, where conflict is more common. This will be further examined in the final step of our estimation strategy.

Finally, we investigate voice and accountability and government effectiveness. We find that both $\mathrm{CO}_{2}$ per capita and $\mathrm{CO}_{2}$ intensity respond positively to increases in voice and accountability, with estimated elasticities of 0.09 and 0.09 , respectively. Government effectiveness has a marginally significant negative effect only on organic water pollutants. While it might have been expected that an effective government would decrease all types of pollution, this assumes that decreasing pollution is one of the government's priorities.

$<$ Table 3 about here $>$ 
We can see from these results that the single most consistent governance factor is the control of corruption. The other governance factors - political stability and voice and accountability - have variable effects which will be further investigated in our sub-sample analysis. The role of the informal sector on pollutant emissions is likely to differ across countries at different stages of development, partly due to the differences in economic structure and the quality of institutions that can enforce environmental laws. We considered two different sub-samples, the OECD sample and the non-OECD sample. These results are presented in Table 4 and Table 5, respectively. The results indicate that our key variable of interest (informal sector) has a negative significant impact on global pollutants $\left(\mathrm{CO}_{2}\right.$ per capita and $\mathrm{CO}_{2}$ intensity), in the OECD sample whereas it has no significant effect on these pollutants in the non-OECD sample. This is not surprising because the OECD sample is likely to have more services in the informal sector. On the other hand, while there is no significant impact of informality on the water pollutants in the OECD sample, there is a strong positive impact on these pollutants in the non-OECD sub-sample.

The difference in the effect of the informal sector between the two sub-samples maybe explained by the difference in the general structure of the economy and the kind of economic activities the informal sector engages in (Elgin and Oztunali, 2014). For instance, the informal sector in developing countries is likely to engage predominantly in activities such as subsistence farming, fishing and services. These activities may contribute more to local pollutants such as water pollution rather than carbon emissions due to both the low capital-intensive and rudimentary technologies that are adopted in this sector.

An interesting finding from the sub-sample analysis is with respect to GDP per capita. In the OECD sample it is negative for four of the pollutants, whereas, in the case of the non-OECD sample, it is positive for all the five pollutants. Specifically, in the OECD sample, GDP per capita has a significant negative impact on $\mathrm{CO}_{2}$ intensity and water pollutant per worker. This suggests that for these two pollutants, there is decoupling of GDP from emission that could come through stringent environmental laws and enforcements, new technology that is less polluting and efficient use of resources such as energy at a certain stage of development and effectiveness of governance institutions. It also does seem to confirm the EKC pattern that pollution decreases with income in more prosperous countries. In the case of the non-OECD sample, the results indicate no evidence of decoupling of GDP per capita from emissions. Thus, the determinants of pollution clearly vary across the sub-samples leading us to conclude that they need to be considered separately. 
Based on these findings from the sub-sample analysis, we also examine the impact of each of our governance indicators on the various pollutants. The results from this analysis are reported in the appendix (Table A1). We find that the governance indicators are clearly more significant in the non-OECD sample than in the OECD sample. More specifically, for the OECD countries, political stability is not significant for any indicator and government effectiveness is only significant at the 10 per cent level for $\mathrm{CO}_{2}$ per capita and the ecological footprint. The only two cases where governance is significant is the impact of control of corruption on organic water pollutants and voice and accountability. For OECD countries, voice and accountability decreases chemical water pollutant but marginally increases the ecological footprint.

For the non-OECD countries, both political stability and control of corruption are highly significant for 4 out of the 5 indicators. Control of corruption decreases both $\mathrm{CO}_{2}$ indicators and water pollutants. It marginally increases the ecological footprint. Political stability increases $\mathrm{CO}_{2}$ emissions but decreases water pollutants and the ecological footprint. Voice and accountability increases $\mathrm{CO}_{2}$ emissions, whereas government effectiveness is largely insignificant but has a weak impact on decreasing water pollutant per worker.

$<$ Table 4 about here $>$

$<$ Table 5 about here $>$

\subsection{Sensitivity Analysis}

In order to check the robustness of our results, we conduct the following sensitivity analysis. First, by ignoring the potential endogeneity of GDP per capita and estimating the reduced-form model by a fixed effect approach. Second, by replacing the informal sector variable with a second proxy, constructed from the first principal components of both government effectiveness and regulatory quality (referred to as informal). These variables (government effectiveness and regularity quality) are directly linked to the size of the informal sector. A country with a lax regulatory environment and an ineffective government is likely to have a large proportion of its economic activities operating in the informal sector relative to a country with a better developed regulatory environment and an effective government. We therefore expect an inverse relationship 
between these two factors (government effectiveness and regularity quality) and the size of the informal sector.

The results for the first sensitivity analysis based on the full sample both for the cases where regulation is represented with informal sector and where it is represented with four different dimensions of governance are reported in the appendix (Table A3). In general, the results are qualitatively similar to our main results for the full sample reported in tables 2 and 3, respectively for the case of the informal sector and that of governance. The estimated elasticity of pollution with respect to the informal sector is positive and significant for all the local pollutants except the case of the ecological footprint, where the sign of the coefficient changes from positive to negative. In the case of governance indicators, once again, the results are largely similar though the level of potential significance of the coefficients varies. This does suggest potential bias on the estimated coefficients due to endogeneity of GDP in the fixed effect model relative to the IVmodel.

The results for the second sensitivity analysis based on the full sample using the constructed proxy for the informal sector (informal2), reported in the appendix (Table A4) are qualitatively similar to our main results. They indicate that informal2 has a positive impact on the global pollutants and negative impact on the local pollutants (except in the case of ecological footprint). However, the magnitude and significance, of this new construct of informality vary as compared to the original index for the informal sector, which includes factors beyond regulation and government effectiveness.

We find that our results are robust to both endogeneity and the measure of the informal sector (broad or narrow measure). The quantitative differences in the magnitude of the estimates, can be attributed to the endogeneity and the measurement bias.

\section{Summary and Conclusions}

The objective of this study is to provide a clear understanding of the effect of the informal sector and the quality of governance on a range of pollutants. The intent is to present empirical evidence on the role of the informal sector on emissions and whether this is conditional on the type of pollutant and the level of a country's development. In addition to assessing the causal effects of the informal sector, we are also interested in investigating the governance mechanisms that 
influence environmental quality, namely, control of corruption, political stability, voice and accountability and government effectiveness. The empirical analysis is based on a panel data consisting of 58 countries and 16 years.

Several interesting findings emerge. First, in general the informal sector tends to positively influence the local pollutants emission but has no significant impact on the global pollutants such as $\mathrm{CO}_{2}$ per capita and $\mathrm{CO}_{2}$ intensity. Given that most activities in the informal sector rely heavily on labour-intensive production techniques (Managi et al., 2009), especially in the developing countries, our results suggest that the consequences of such techniques on $\mathrm{CO}_{2}$ emission would be small due to the low energy utilisation of such techniques. In the case of the OECD countries, it is likely that the impact of the informal sector may be negative for such global pollutants, due to the low-capital intensive nature of production activity in the informal sector relative to the formal sector. In addition, OECD countries have better institutions for monitoring and regulating pollution. Second, we find evidence for the impact of four specific governance variables on pollutant emissions. In particular, the control of corruption has a negative effect on pollutant emissions, irrespective of the global or local nature of the pollutant. Political stability on the other hand has a positive impact on global pollutants but a negative impact on local pollutants. Voice and accountability has a significant positive effect on global pollutants.

These results have implications for policy-making, especially in the non-OECD countries. First, control of corruption is clearly a significant factor improving environmental quality especially in the non-OECD countries. Thus, environmental policy in the non-OECD countries should focus on improving the institutions of governance that help control corruption and improve governance. Secondly, the GDP per capita had a negative effect on pollutants emission for the OECD countries, suggests that over the sampled period, OECD countries have to a certain extent succeeded in decoupling economic activities from energy use and consequently pollution. In contrast, the non-OECD countries show increase in pollutant emission with increasing economic growth. Non-OECD countries lack stringent environmental controls and implementation of incentive-based environmental policies, especially in their informal sector. The non-OECD countries will benefit from improving their institutions to ensure good monitoring and regulation of pollution.

Our results provide insights into the role of informal sector and governance on pollutant emission, thereby providing environmental policy direction for countries with a significant size of the 
informal sector. Environmental pollution controls in countries with poor governance institutions are weak. The efficacy of an environmental policy for any country with a huge informal sector will be low unless efforts are made to regulate the informal sector (i.e. to formalise it). To the extent that such efforts are to succeed, governance, especially control of corruption needs to be improved.

\section{References}

Andreoni, J. \& Levinson, A. 2001. The Simple Analytics of the Environmental Kuznets Curve, Journal of Public Economics, Vol. 80, pp. 269-286.

Baltagi, B. H. 2005. Econometric Analysis of Panel Data. Chichester: John Wiley \& Sons.

Barrett, S. \& Graddy, K. 2000. Freedom, Growth and the Environment, Environment and Development Economics, Vol. 5, pp. 433-456.

Bernauer, T. and Koubi, V., 2009. Effects of political institutions on air quality. Ecological Economics, 68(5), pp.1355-1365

Bhattarai, M. \& Hammig, M. 2001. Institutions and the Environmental Kuznets Curve for Deforestation: A Cross-country Analysis for Latin America, Africa and Asia, World Development, Vol. 29 (6), pp. 995-1010.

Bloom, D. E., Canning, D. \& Sevilla, J. 2001. Economic Growth and the Demographic Transition, National Bureau of Economic Research, Working Paper No. 8685.

Bloom, D. E., Canning, D. \& Sevilla, J. 2004. The Effect of Health on Economic Growth: A Production Function Approach, World Development, Vol. 32 (1), pp. 1-13.

Biswas, A.K., Farzanegan, M.R. and Thum, M., 2012. Pollution, shadow economy and corruption: Theory and evidence. Ecological Economics, Vol.75, pp.114-125.

Bovenberg, A. L., and Smulders, J. (1995). Environmental quality and pollution- augmenting technological change in a two-sector endogenous growth model. Journal of Public Economics, Vol. 57, No. 3, pp. 353-360.

Brännlund, R, Karimu, A. and Söderholm, P., 2017. Convergence in carbon dioxide emissions and the role of growth and institutions: a parametric and non-parametric analysis. Environmental Economics and Policy Studies, Vol.19 (2), pp.359-390.

Brock, W. A., and Taylor, M. S. 2005. Economic growth and the environment: a review of theory and empirics, In Aghion, P., and Durlauf, S. N. (Eds.), Handbook of Economic Growth, Elsevier, pp. 1750-1821.

Brock, W. A., and Taylor, M. S. 2010. The green Solow model, Journal of Economic Growth, Vol. 15, pp. 127-153. 
Congleton, R.D., 1992. Political institutions and pollution control. The review of economics and statistics, pp.412-421.

Dasgupta, S. \& Maler, 1995. Poverty, Institutions and the Environmental Resource-base, Handbook of Development Economics, Vol. 3(1), pp. 2371-2463.

Dasgupta, S., Mody, A., Roy, S. \& Wheeler, D. 2001. Environmental Regulation and Development: A Cross-country Empirical Analysis. Oxford Development Studies, Vol. 29 (2), pp. $173-187$.

Dasgupta, S., Laplante, B., Wang, H. \&Wheeler, D. 2002. Confronting the Environmental Kuznets Curve, Journal of Economic Perspectives, Vol. 16 (1), pp. 147-168.

Dijkgraaf, E. \& Vollebergh, H.R.J. 1998. Growth and/or Environment: Is There a Kuznets Curve for Carbon Emissions?, Paper presented at the 2nd biennial meeting of the European Society for Ecological Economics, Geneva, 4-7th March.

Dijkgraaf, E. \& Vollebergh, H.R.I. 2005. A Test for Parameter Homogeneity in $\mathrm{CO}_{2}$ Panel EKC Estimations, Environmental and Resource Economics, Vol. 32 (2), pp. 229-239.

Dinda, S. \& Coondoo, D. 2002. Causality Between Income and Emission: A Country Groupspecific Econometric Analysis, Ecological Economics, Vol. 40 (3), pp. 351-367.

Dinda, S. 2004. Environmental Kuznets Curve Hypothesis: A Survey, Ecological Economics, Vol. 49 (4), pp. 431-455.

Elgin, C. and Oztunali, O., 2014. Pollution and informal economy. Economic Systems, 38(3), pp. 333- 349 .

Farzin, Y.H. \& Bond, C.A. 2006. Democracy and Environmental Quality, Journal of Development Economics, Vol. 81(1), pp. 213-235.

Galeotti, M., Manera, M. \& Lanza, A. 2009. On the Robustness of Robustness Checks of the Environmental Kuznets Curve Hypothesis, Environmental and Resource Economics, Vol. 42, pp. 551-574.

Gani, A. 2012. The Relationship between Good Governance and Carbon Dioxide Emissons: Evidence from Developing Countries. Journal of Economic Development, Vol. 37, No. 1, pp. 77-93.

Grossman, G. M. \& Krueger, A. B. 1991. Environmental Impacts of North American Free Trade Agreement, National Bureau of Economic Research, Working Paper No. 3914.

Grossman, G. M. \& Krueger, A. B. 1995. Economic Growth and the Environment, The Quarterly Journal of Economics, Vol. 110 (2), pp. 353-377.

Hahn, J. \& Newey, W. 2004. Jackknife and Analytical Bias Reduction for Nonlinear Panel Models, Econometrica, Vo. 72 (4), pp. 1295-1319. 
Hansen, L.P. 1982. Large Sample Properties of Generalized Method of Moments Estimators, Econometrica, Vol. 50 (4), pp. 1029-1054.

Harbaugh, W., Levinson, A. \& Wilson, D. 2000. Reexamining the Empirical Evidence for an Environmental Kuznets Curve, National Bureau of Economic Research, Working Paper No. 7711.

He, J. 2007. Is the Environmental Kuznets Curve Hypothesis Valid for Developing Countries? A Survey, Groupe de Recherche en Économie et Développement International, Working Paper 07-03.

Hettige, H., Huq, M., Pargal, S. and Wheeler, D., 1996. Determinants of pollution abatement in developing countries: evidence from South and Southeast Asia. World Development, 24(12), pp.1891-1904.

Hettige, H., Dasgupta, S. \& Wheeler, D. 2000. What Improves Environmental Compliance? Evidence from Mexican Industry, Journal of Environmental Economics and Management, Vol. 39 (1), pp. 39-66.

Holtz-Eakin, D. \& Selden, T. 1995. Stoking the Fires? $\mathrm{CO}_{2}$ Emissions and Economic Growth, Journal of Public Economics, Vol. 57(1), pp. 85-101.

Hossain, M. S., Santhanam, A., Norulaini, N. \& Mohd Omar, A. K. 2011. Clinical Solid Waste Management Practices and its Impact on Human Health and Environment - A Review, Waste Management, Vol. 32, pp. 754-766.

John, A. \& Pecchenino, R. 1994. An Overlapping Generations Model of Growth and the Environment, The Economic Journal, Vol. 104 (427), pp. 1393-1410.

Kaufman, D., Kraay, A., and Mastuzzi, M. 2010, 'The Worldwide Governance Indicators: A Summary of Methodology, Data and Analytical Issues,' World Bank Policy Research Working Paper No. 5430.

Kuznets, S. 1995. Economic Growth and Income Inequality, The American Economic Review, Vol. 45 (1), pp. 1-28.

Leitao, A. 2010. Corruption and the Environmental Kuznets Curve: Empirical evidence for Sulfur. Ecological Economics, Vol. 69 (11), pp. 2191- 2201.

Lin Lawell, C. \& Liscow, Z. 2013. Endogeneity in the Environmental Kuznets Curve: An Instrumental Variables Approach, American Journal of Environmental Economics, Vol. 95(2), pp. 268-274.

Lopez, R. 1994. The Environment as a Factor of Production: The Effects of Economic Growth and Trade Liberalization, Journal of Environmental Economics and Management, Vol. 27 (2), pp. 163-184. 
Muller-Furstenberger, G. \& Wagner, M. 2007. Exploring the Environmental Kuznets Hypothesis: Theoretical and Econometric Problems, Ecological Economics, Vol. 62 (3-4), pp. 648-660.

Munasinghe, M. 1999. Is Environmental Degradation an Inevitable Consequence of Economic Growth: Tunneling through the Environmental Kuznets Curve, Ecological Economics, Vol. 29 (1), pp. 89-109.

Narayan, P. \& Narayan, S. 2010. Carbon Dioxide Emissions and Economic Growth: Panel Data Evidence from Developing Countries, Energy Policy, Vol. 38 (1), pp. 661-666.

Ordás Criado, C., Valente, S., and Stengos, T. 2011. Growth and pollution convergence: Theory and evidence. Journal of Environmental Economics and Management, Vol. 62, No. 2, pp. 199214.

Panatayou, T. 1993. Empirical Tests and Policy Analysis of Environmental Degradation at Different Stages of Economic Development, Technology and Employment Programme (ILO), Geneva.

Pargal, S. \& Wheeler, D. 1996. Informal Regulation of Industrial Pollution in Developing Countries: Evidence from Indonesia. Journal of Political Economy, Vol. 104 (6), pp. 13141327.

Richmond, A. \& Kaufmann, R. 2006. Is There a Turning Point in the Relationship Between Income and Energy Use and/or Carbon Emissions? Ecological Economics, Vol. 56(2), pp. 176-189.

Schaffer, M.E. 2012. XTIVREG2: Stata Module to Perform Extended IV/2SLS, GMM and AC/HAC, LIML and K-class Regression for Panel Data Models, http://ideas.repec.org/c/boc/bocode/s456501.html

Schneider, F., Buehn, A., \& Montenegro, C. E. 2010. New Estimates for the Shadow Economies all over the World, International Economic Journal, Vol. 24 (4), pp. 443-461.

Selden, T. \& Song, D. 1995. Neoclassical Growth, the J Curve for Abatement, and the Inverted U Curve for Pollution, Journal of Environmental Economics and Management, Vol. 29 (2), pp. 162-168.

Shafik, N. \& Bandyopadhyay, S. 1992. Economic Growth and Environmental Quality: Time Series and Cross-country Evidence, The World Bank, Working Paper No. 904.

Stern, D. I. 2004. The Rise and Fall of the Environmental Kuznets Curve, World Development, Vol.32 (8), pp. 1419-1439.

Stokey, N. 1998. Are there Limits to Growth?, International Economic Review, Vol. 39 (1), pp. 1-31. Torras, M. \& Boyce, J.K. 1998. Income, Inequality, and Pollution: A Reassessment of the Environmental Kuznets Curve, Ecological Economics, Vol. 25 (2), pp. 147-160. 
United States Environmental Protection Agency. 2017. Climate Change, http://www.epa.gov/climatechange/ghgemissions/gases/CO2.html.

Van der Ploeg, F., and Withagen, C., 1991. Pollution control and the Ramsey problem, Environmental and Resource Economics, Vol.1, No. 2, pp. 215-236.

World Bank. 1992. World Development Report 1992: Development and the Environment. Oxford University Press: New York.

World Bank. 2012. World Development Indicators, The World Bank, New York.

You, W.H., Zhu, H.M., Yu, K. and Peng, C., 2015. Democracy, financial openness, and global carbon dioxide emissions: Heterogeneity across existing emission levels. World Development, 66, pp.189-207. 


\section{TABLES}

Table 1: Descriptive Statistics

\begin{tabular}{lcccc}
\hline Variable & Mean & Standard Deviation & Minimum & Maximum \\
\hline Informal sector & 32.644 & 12.593 & 8.100 & 68.300 \\
Agriculture value added & 14.832 & 13.378 & 0.034 & 62.383 \\
Industry value added & 29.928 & 12.881 & 5.394 & 95.708 \\
Population density & 254.222 & 1308.201 & 0.136 & 17703.500 \\
Urbanisation & 55.403 & 24.103 & 7.418 & 100.000 \\
Energy use per capita & 2397.966 & 2854.619 & 9.021 & 23599.080 \\
Trade & 88.352 & 47.558 & 0.000 & 460.471 \\
Age dependency ratio & 63.677 & 18.041 & 16.926 & 113.908 \\
Carbon-dioxide per capita & 4.905 & 6.800 & 0.013 & 68.626 \\
Carbon-dioxide intensity & 2.215 & 0.926 & 0.163 & 6.141 \\
Water pollutant per worker & 0.186 & 0.059 & 0.091 & 0.451 \\
Water pollutant & 10.829 & 5.118 & 0.334 & 55.907 \\
Ecological footprint & 2.801 & 2.027 & 0.437 & 12.195 \\
Control Corruption & 0.426 & 0.222 & 0.001 & 1.000 \\
Political Stability & 0.627 & 0.188 & 0.001 & 1.000 \\
Voice \& Accountability & 0.554 & 0.246 & 0.001 & 1.000 \\
Government Effectiveness & 0.504 & 0.205 & 0.001 & 1.000 \\
\hline
\end{tabular}


Table 2: Impact of Informal Sector on pollution, IV-GMM- FE estimations

\begin{tabular}{|c|c|c|c|c|c|}
\hline & $\begin{array}{c}\mathrm{Ln} \mathrm{CO}_{2} \text { per } \\
\text { capita }\end{array}$ & $\begin{array}{l}\mathrm{Ln} \mathrm{CO}_{2} \text { per } \\
\text { energy use }\end{array}$ & $\begin{array}{l}\text { Ln water } \\
\text { pollutant } \\
\text { Per worker }\end{array}$ & $\begin{array}{l}\text { Ln water } \\
\text { pollutant } \\
\text { chemical }\end{array}$ & $\begin{array}{l}\text { Ln ecological } \\
\text { footprint }\end{array}$ \\
\hline \multirow[t]{2}{*}{$\begin{array}{l}\text { Ln GDP per } \\
\text { capita }\end{array}$} & $0.407^{* *}$ & 0.212 & 0.0919 & $0.799^{* * *}$ & $0.792^{* * *}$ \\
\hline & $(0.158)$ & $(0.152)$ & $(0.0894)$ & $(0.287)$ & $(0.208)$ \\
\hline \multirow[t]{2}{*}{$\begin{array}{l}\text { Ln informal } \\
\text { sector }\end{array}$} & -0.0905 & -0.281 & $0.773^{* * *}$ & $2.469^{* * *}$ & $0.940^{*}$ \\
\hline & $(0.390)$ & $(0.400)$ & $(0.294)$ & $(0.942)$ & $(0.522)$ \\
\hline \multirow[t]{2}{*}{$\begin{array}{l}\text { Ln Agric value } \\
\text { added }\end{array}$} & 0.0170 & 0.0280 & $-0.0465^{* *}$ & 0.0700 & 0.0394 \\
\hline & $(0.0244)$ & $(0.0261)$ & $(0.0200)$ & $(0.0632)$ & $(0.0336)$ \\
\hline \multirow[t]{2}{*}{$\begin{array}{l}\text { Ln industry } \\
\text { value added }\end{array}$} & -0.0445 & $-0.0782^{*}$ & 0.0409 & $-0.479^{* * *}$ & 0.0716 \\
\hline & $(0.0408)$ & $(0.0435)$ & $(0.0377)$ & $(0.121)$ & $(0.0618)$ \\
\hline \multirow[t]{2}{*}{$\begin{array}{l}\text { Ln population } \\
\text { density }\end{array}$} & $0.508^{* * *}$ & $0.488^{* * *}$ & 0.0867 & $0.780^{* *}$ & 0.344 \\
\hline & $(0.177)$ & $(0.186)$ & $(0.0961)$ & $(0.308)$ & $(0.234)$ \\
\hline \multirow[t]{2}{*}{ Ln urbanisation } & $0.560^{* * *}$ & 0.252 & -0.106 & $-0.978^{*}$ & $-0.676^{* * *}$ \\
\hline & $(0.168)$ & $(0.183)$ & $(0.146)$ & $(0.505)$ & $(0.227)$ \\
\hline \multirow[t]{2}{*}{ Ln energy use } & $0.591^{* * *}$ & & 0.0595 & -0.105 & $0.225^{* * *}$ \\
\hline & $(0.0523)$ & & $(0.0368)$ & $(0.117)$ & $(0.0715)$ \\
\hline \multirow[t]{2}{*}{ Ln trade } & 0.0428 & 0.0127 & -0.0340 & $0.196^{* * *}$ & -0.0353 \\
\hline & $(0.0289)$ & $(0.0295)$ & $(0.0223)$ & $(0.0704)$ & $(0.0403)$ \\
\hline Sample size & 1016 & 1016 & 490 & 473 & 935 \\
\hline Hanson-j stat & 7.894 & 4.813 & 2.821 & 4.278 & 8.034 \\
\hline P-value & $(0.048)$ & $(0.090)$ & $(0.244)$ & $(0.118)$ & $(0.018)$ \\
\hline Anderson & 100.8 & 114.1 & 129.8 & 120.9 & 97.61 \\
\hline P-value & $(0.000)$ & $(0.000)$ & $(0.000)$ & $(0.000)$ & $(0.000)$ \\
\hline $\begin{array}{l}\text { Cragg Donald F- } \\
\text { stats }\end{array}$ & 26.10 & 39.78 & 49.47 & 45.76 & 33.78 \\
\hline
\end{tabular}

Standarderrors in parentheses, yes denote time dummies are included in the model, ${ }^{*} p<0.10,{ }^{* *} p<0.05,{ }^{* * *} p<0.01$. 
Table 3: Impact of Governance on Pollution, IV-GMM- FE estimations

\begin{tabular}{|c|c|c|c|c|c|}
\hline & $\begin{array}{c}\mathrm{Ln} \mathrm{CO}_{2} \text { per } \\
\text { capita }\end{array}$ & $\begin{array}{l}\mathrm{Ln} \mathrm{CO}_{2} \text { per } \\
\text { energy use }\end{array}$ & $\begin{array}{l}\text { Ln water } \\
\text { pollutant } \\
\text { Per worker }\end{array}$ & $\begin{array}{l}\text { Ln water } \\
\text { pollutant } \\
\text { chemical }\end{array}$ & $\begin{array}{l}\text { Ln ecological } \\
\text { footprint }\end{array}$ \\
\hline \multirow[t]{2}{*}{ Ln GDP per capita } & $0.290^{* *}$ & $0.290^{* *}$ & 0.018 & 0.386 & $0.695^{* * *}$ \\
\hline & $(0.133)$ & $(0.133)$ & $(0.080)$ & $(0.284)$ & $(0.218)$ \\
\hline \multirow[t]{2}{*}{ Ln Agric value added } & -0.014 & -0.014 & -0.031 & -0.029 & 0.067 \\
\hline & $(0.024)$ & $(0.024)$ & $(0.020)$ & $(0.066)$ & $(0.041)$ \\
\hline \multirow[t]{2}{*}{$\begin{array}{l}\text { Ln industry value } \\
\text { added }\end{array}$} & 0.026 & 0.026 & 0.042 & -0.159 & 0.050 \\
\hline & $(0.036)$ & $(0.036)$ & $(0.040)$ & $(0.156)$ & $(0.060)$ \\
\hline \multirow[t]{2}{*}{ Ln population density } & $0.474^{* * *}$ & $0.474^{* * *}$ & 0.058 & 0.464 & 0.224 \\
\hline & $(0.141)$ & $(0.141)$ & $(0.139)$ & $(0.452)$ & $(0.225)$ \\
\hline \multirow[t]{2}{*}{ Ln urbanisation } & $0.481^{* * *}$ & $0.481^{* * *}$ & -0.116 & $-1.144^{* *}$ & -0.304 \\
\hline & $(0.145)$ & $(0.145)$ & $(0.144)$ & $(0.495)$ & $(0.235)$ \\
\hline \multirow[t]{2}{*}{ Ln energy use } & $0.719^{* * *}$ & $-0.281^{* * *}$ & 0.038 & 0.033 & $0.249^{* * *}$ \\
\hline & $(0.055)$ & $(0.055)$ & $(0.036)$ & $(0.117)$ & $(0.087)$ \\
\hline \multirow[t]{2}{*}{ Ln trade } & $0.072^{* * *}$ & $0.072^{* * *}$ & -0.033 & 0.035 & $-0.069^{*}$ \\
\hline & $(0.025)$ & $(0.025)$ & $(0.023)$ & $(0.075)$ & $(0.040)$ \\
\hline \multirow[t]{2}{*}{$\begin{array}{l}\text { Ln Control } \\
\text { corruption }\end{array}$} & $-0.098^{* * *}$ & $-0.098^{* * *}$ & $-0.048^{*}$ & $-0.375^{* * *}$ & 0.065 \\
\hline & $(0.027)$ & $(0.027)$ & $(0.028)$ & $(0.092)$ & $(0.042)$ \\
\hline \multirow[t]{2}{*}{ Ln Political Stability } & $0.103^{* * *}$ & $0.103^{* * *}$ & -0.014 & $-0.288^{* * *}$ & $-0.082^{*}$ \\
\hline & $(0.030)$ & $(0.030)$ & $(0.030)$ & $(0.096)$ & $(0.045)$ \\
\hline \multirow[t]{2}{*}{$\begin{array}{l}\text { Ln Voice \& } \\
\text { Accountability }\end{array}$} & $0.090^{* * *}$ & $0.090^{* * *}$ & 0.016 & 0.058 & 0.008 \\
\hline & $(0.028)$ & $(0.028)$ & $(0.022)$ & $(0.071)$ & $(0.043)$ \\
\hline \multirow[t]{2}{*}{$\begin{array}{l}\text { Ln Government } \\
\text { effectiveness }\end{array}$} & 0.071 & 0.071 & $-0.103^{*}$ & -0.275 & -0.059 \\
\hline & $(0.070)$ & $(0.070)$ & $(0.054)$ & $(0.190)$ & $(0.111)$ \\
\hline Sample size & 1138 & 1138 & 441 & 418 & 910 \\
\hline Hanson-j stat & 6.832 & 6.832 & 2.584 & 3.504 & 5.006 \\
\hline P-value & 0.032 & 0.0328 & 0.275 & 0.173 & 0.0818 \\
\hline Anderson & 88.09 & 88.09 & 113.1 & 88.93 & 67.86 \\
\hline P-value & $(0.000)$ & $(0.000)$ & $(0.000)$ & $(0.000)$ & $(0.000)$ \\
\hline Cragg Donald F-stats & 30.05 & 30.05 & 41.69 & 31.81 & 23.02 \\
\hline
\end{tabular}

Standarderrorsin parentheses, yes denotetimedummiesareincludedinthemodel, ${ }^{*} p<0.10,{ }^{* *} p<0.05,{ }^{* * *} p<0.01$. 
Table 4: Impact of Informal Sector on pollution, IV-GMM- FE estimations-OECD

\begin{tabular}{|c|c|c|c|c|c|}
\hline & $\begin{array}{c}\mathrm{Ln} \mathrm{CO}_{2} \text { per } \\
\text { capita }\end{array}$ & $\begin{array}{l}\mathrm{Ln} \mathrm{CO}_{2} \text { per } \\
\text { energy use }\end{array}$ & $\begin{array}{l}\text { Ln water } \\
\text { pollutant } \\
\text { Per worker }\end{array}$ & $\begin{array}{l}\text { Ln water } \\
\text { pollutant } \\
\text { chemical }\end{array}$ & $\begin{array}{l}\text { Ln ecological } \\
\text { footprint }\end{array}$ \\
\hline \multirow[t]{2}{*}{ Ln GDP per capita } & -0.175 & $-0.262^{*}$ & $-0.552^{* *}$ & -0.434 & $0.509^{*}$ \\
\hline & $(0.138)$ & $(0.141)$ & $(0.214)$ & $(0.335)$ & $(0.266)$ \\
\hline \multirow[t]{2}{*}{ Ln informal sector } & $-0.584^{* *}$ & $-0.671^{* *}$ & 0.167 & -1.161 & -0.315 \\
\hline & $(0.279)$ & $(0.295)$ & $(0.499)$ & $(0.779)$ & $(0.521)$ \\
\hline \multirow[t]{2}{*}{$\begin{array}{l}\text { Ln Agric value } \\
\text { added }\end{array}$} & 0.0124 & 0.0124 & $-0.0689^{*}$ & $-0.204^{* * *}$ & -0.00878 \\
\hline & $(0.0269)$ & $(0.0271)$ & $(0.0366)$ & $(0.0571)$ & $(0.0483)$ \\
\hline \multirow[t]{2}{*}{$\begin{array}{l}\text { Ln industry value } \\
\text { added }\end{array}$} & -0.0387 & -0.0571 & $-0.169^{*}$ & $-0.317^{* *}$ & $0.167^{*}$ \\
\hline & $(0.0532)$ & $(0.0527)$ & $(0.0982)$ & $(0.153)$ & $(0.0955)$ \\
\hline \multirow[t]{2}{*}{$\begin{array}{l}\text { Ln population } \\
\text { density }\end{array}$} & -0.0140 & -0.143 & 0.285 & -0.388 & $-0.684^{*}$ \\
\hline & $(0.203)$ & $(0.191)$ & $(0.287)$ & $(0.448)$ & $(0.365)$ \\
\hline \multirow[t]{2}{*}{ Ln urbanisation } & -0.00275 & -0.0701 & 0.158 & -0.551 & -0.412 \\
\hline & $(0.243)$ & $(0.246)$ & $(0.342)$ & $(0.533)$ & $(0.441)$ \\
\hline \multirow[t]{2}{*}{ Ln energy use } & $0.874^{* * *}$ & & $0.491^{* * *}$ & 0.204 & $0.277^{*}$ \\
\hline & $(0.0682)$ & & $(0.117)$ & $(0.183)$ & $(0.141)$ \\
\hline \multirow[t]{2}{*}{ Ln trade } & -0.0375 & -0.0555 & -0.0288 & -0.0421 & -0.0386 \\
\hline & $(0.0423)$ & $(0.0415)$ & $(0.0530)$ & $(0.0827)$ & $(0.0755)$ \\
\hline Sample size & 257 & 257 & 188 & 188 & 248 \\
\hline Hanson-j stat & 1.336 & 0.679 & 11.64 & 4.161 & 2.028 \\
\hline $\mathrm{P}$-value & $(0.721)$ & $(0.712)$ & $(0.003)$ & $(0.125)$ & $(0.363)$ \\
\hline Anderson & 158.1 & 126.9 & 100.1 & 100.1 & 121.8 \\
\hline P-value & $(0.000)$ & $(0.000)$ & $(0.000)$ & $(0.000)$ & $(0.000)$ \\
\hline $\begin{array}{l}\text { Cragg Donald F- } \\
\text { stats }\end{array}$ & 52.26 & 52.38 & 43.23 & 43.23 & 49.78 \\
\hline
\end{tabular}

Standard errors in parentheses, ${ }^{*} p<0.10,{ }^{* *} p<0.05,{ }^{* * *} p<0.01$ 
Table 5: Impact of Informal Sector on pollution, IV-GMM-FE estimations-Non-OECD

\begin{tabular}{|c|c|c|c|c|c|}
\hline & $\begin{array}{l}\mathrm{Ln} \mathrm{CO}_{2} \text { per } \\
\text { capita }\end{array}$ & $\begin{array}{l}\mathrm{Ln} \mathrm{CO}_{2} \text { per } \\
\text { energy use }\end{array}$ & $\begin{array}{l}\text { Ln water } \\
\text { Pollutant } \\
\text { Per worker }\end{array}$ & $\begin{array}{l}\text { Ln water } \\
\text { pollutant } \\
\text { chemical }\end{array}$ & $\begin{array}{l}\text { Ln ecological } \\
\text { footprint }\end{array}$ \\
\hline \multirow[t]{2}{*}{$\begin{array}{l}\text { Ln GDP per } \\
\text { capita }\end{array}$} & $0.541^{* *}$ & $0.519^{*}$ & $0.214^{* *}$ & $1.209^{* * *}$ & $1394^{* * *}$ \\
\hline & $(0.274)$ & $(0.292)$ & $(0.0995)$ & $(0.398)$ & $(0.398)$ \\
\hline \multirow[t]{2}{*}{$\begin{array}{l}\text { Ln informal } \\
\text { sector }\end{array}$} & 0.168 & 0.344 & $0.978^{* * *}$ & $3.904^{* * *}$ & $2.364^{* *}$ \\
\hline & $(0.644)$ & $(0.708)$ & $(0.348)$ & $(1.392)$ & $(0.945)$ \\
\hline \multirow[t]{2}{*}{$\begin{array}{l}\text { Ln Agric value } \\
\text { added }\end{array}$} & 0.0305 & 0.0696 & -0.0266 & $0.189^{*}$ & $0.111^{*}$ \\
\hline & $(0.0380)$ & $(0.0433)$ & $(0.0253)$ & (0.0999) & $(0.0587)$ \\
\hline \multirow[t]{2}{*}{$\begin{array}{l}\text { Ln industry } \\
\text { value added }\end{array}$} & -0.0590 & $-0.0916^{*}$ & 0.0591 & $-0.527^{* * *}$ & 0.0860 \\
\hline & $(0.0495)$ & $(0.0528)$ & $(0.0432)$ & $(0.176)$ & $(0.0854)$ \\
\hline \multirow[t]{2}{*}{$\begin{array}{l}\text { Ln population } \\
\text { density }\end{array}$} & $0.643^{* *}$ & $0.895^{* *}$ & 0.143 & $0.911^{* *}$ & $1.189^{* *}$ \\
\hline & $(0.324)$ & $(0.370)$ & $(0.104)$ & $(0.424)$ & $(0.470)$ \\
\hline \multirow[t]{2}{*}{ Ln urbanisation } & $0.542^{* *}$ & 0.106 & $-0.283^{*}$ & -1.077 & $-0.862^{* * *}$ \\
\hline & $(0.217)$ & $(0.248)$ & $(0.164)$ & $(0.735)$ & $(0.320)$ \\
\hline \multirow[t]{2}{*}{ Ln energy use } & $0.552^{* * *}$ & & -0.00242 & -0.118 & $0.176^{*}$ \\
\hline & $(0.0653)$ & & $(0.0376)$ & $(0.150)$ & $(0.0975)$ \\
\hline \multirow[t]{2}{*}{ Ln trade } & $0.0611^{*}$ & 0.0320 & -0.0232 & $0.251^{* *}$ & -0.00680 \\
\hline & $(0.0362)$ & $(0.0370)$ & $(0.0246)$ & $(0.0982)$ & $(0.0573)$ \\
\hline Sample size & 759 & 759 & 302 & 285 & 687 \\
\hline Hansen-j stat & 5.833 & 3.611 & 0.980 & 6.253 & 2.939 \\
\hline P-value & 0.120 & 0.164 & 0.613 & 0.0439 & 0.230 \\
\hline Anderson & 35.73 & 33.88 & 76.61 & 70.93 & 35.10 \\
\hline P-value & 0.000 & 0.000 & 0.000 & 0.000 & 0.000 \\
\hline $\begin{array}{l}\text { Cragg Donald F- } \\
\text { stats }\end{array}$ & 8.916 & 11.29 & 28.57 & 26.31 & 11.69 \\
\hline
\end{tabular}




\section{APPENDIX}

Table A1: Governance impact, OECD sample

\begin{tabular}{|c|c|c|c|c|c|}
\hline & Ln $\mathrm{CO}_{2}$ per capita & $\begin{array}{l}\mathrm{Ln} \mathrm{CO}_{2} \text { per } \\
\text { energy use }\end{array}$ & $\begin{array}{l}\text { Ln water } \\
\text { Pollutant } \\
\text { Per worker }\end{array}$ & $\begin{array}{l}\text { Ln water } \\
\text { pollutant } \\
\text { chemical }\end{array}$ & $\begin{array}{l}\text { Ln ecological } \\
\text { footprint }\end{array}$ \\
\hline \multirow[t]{2}{*}{ Ln GDP per capita } & 0.022 & -0.103 & $-0.462^{*}$ & -0.259 & 0.212 \\
\hline & $(0.171)$ & $(0.168)$ & $(0.244)$ & $(0.434)$ & $(0.268)$ \\
\hline \multirow[t]{2}{*}{$\begin{array}{l}\text { Ln Agric value } \\
\text { added }\end{array}$} & -0.021 & -0.011 & 0.021 & $-0.223^{* * *}$ & -0.009 \\
\hline & $(0.031)$ & $(0.033)$ & $(0.044)$ & $(0.079)$ & $(0.049)$ \\
\hline \multirow[t]{2}{*}{$\begin{array}{l}\text { Ln industry value } \\
\text { added }\end{array}$} & $0.112^{*}$ & 0.041 & $-0.203^{* *}$ & $-0.312^{*}$ & $0.260^{* * *}$ \\
\hline & $(0.058)$ & $(0.060)$ & $(0.099)$ & $(0.177)$ & $(0.091)$ \\
\hline \multirow[t]{2}{*}{$\begin{array}{l}\text { Ln population } \\
\text { density }\end{array}$} & 0.068 & $-0.445^{*}$ & 0.074 & 0.298 & $-0.931^{* *}$ \\
\hline & $(0.263)$ & $(0.243)$ & $(0.353)$ & $(0.628)$ & $(0.394)$ \\
\hline \multirow[t]{2}{*}{ Ln urbanisation } & 0.528 & 0.387 & -0.056 & -0.578 & -0.684 \\
\hline & $(0.340)$ & $(0.354)$ & $(0.463)$ & $(0.825)$ & $(0.509)$ \\
\hline \multirow[t]{2}{*}{ Ln energy use } & $0.614^{* * *}$ & & $0.369^{* * *}$ & 0.060 & $0.419^{* * *}$ \\
\hline & $(0.080)$ & & $(0.117)$ & $(0.208)$ & $(0.143)$ \\
\hline \multirow[t]{2}{*}{ Ln trade } & -0.074 & $-0.136^{* *}$ & -0.083 & 0.083 & $-0.158^{*}$ \\
\hline & $(0.052)$ & $(0.054)$ & $(0.082)$ & $(0.147)$ & $(0.080)$ \\
\hline \multirow[t]{2}{*}{$\begin{array}{l}\text { Ln Control of } \\
\text { corruption }\end{array}$} & -0.040 & -0.064 & $-0.227^{* *}$ & 0.136 & -0.036 \\
\hline & $(0.077)$ & $(0.083)$ & $(0.087)$ & $(0.156)$ & $(0.108)$ \\
\hline \multirow[t]{2}{*}{ Ln Political stability } & -0.0004 & -0.017 & 0.064 & 0.044 & -0.081 \\
\hline & $(0.072)$ & $(0.077)$ & $(0.089)$ & $(0.160)$ & $(0.105)$ \\
\hline \multirow[t]{2}{*}{$\begin{array}{l}\text { Ln Voice \& } \\
\text { accountability }\end{array}$} & 0.002 & 0.076 & -0.133 & $-0.590^{* *}$ & $0.270^{*}$ \\
\hline & $(0.111)$ & $(0.120)$ & $(0.144)$ & $(0.256)$ & $(0.159)$ \\
\hline \multirow[t]{2}{*}{$\begin{array}{l}\text { Ln Government } \\
\text { Effectiveness }\end{array}$} & $0.175^{*}$ & 0.146 & -0.143 & 0.257 & $0.272^{*}$ \\
\hline & $(0.100)$ & $(0.108)$ & $(0.139)$ & $(0.247)$ & $(0.143)$ \\
\hline Sample size & 256 & 256 & 163 & 163 & 220 \\
\hline Hanson-j stat & 2.564 & 0.552 & 6.023 & 2.226 & 8.392 \\
\hline P-value & 0.278 & 0.759 & 0.049 & 0.329 & 0.015 \\
\hline Anderson & 92.88 & 96.78 & 60.36 & 60.36 & 75.55 \\
\hline P-value & $(0.000)$ & $(0.000)$ & $(0.000)$ & $(0.000)$ & $(0.000)$ \\
\hline $\begin{array}{l}\text { Cragg Donald F- } \\
\text { stats }\end{array}$ & 34.72 & 36.68 & 21.76 & 21.76 & 27.64 \\
\hline
\end{tabular}

Standard errors in parentheses, ${ }^{*} p<0.10,{ }^{* *} p<0.05,{ }^{* * *} p<0.01$ 
Table A2: Governance effect on NON-OECD sample

\begin{tabular}{|c|c|c|c|c|c|}
\hline & $\mathrm{Ln} \mathrm{CO}_{2}$ per capita & $\begin{array}{l}\mathrm{Ln} \mathrm{CO}_{2} \text { per } \\
\text { energy use }\end{array}$ & $\begin{array}{l}\text { Ln water } \\
\text { Pollutant } \\
\text { Per worker }\end{array}$ & $\begin{array}{l}\text { Ln water } \\
\text { pollutant } \\
\text { chemical }\end{array}$ & $\begin{array}{c}\text { Ln ecological } \\
\text { footprint }\end{array}$ \\
\hline \multirow[t]{2}{*}{ Ln GDP per capita } & 0.251 & 0.176 & 0.160 & 0.467 & $1.338^{* *}$ \\
\hline & $(0.250)$ & $(0.246)$ & $(0.120)$ & $(0.514)$ & $(0.521)$ \\
\hline \multirow[t]{2}{*}{$\begin{array}{l}\text { Ln Agric value } \\
\text { added }\end{array}$} & -0.021 & -0.015 & -0.024 & 0.030 & $0.183^{* *}$ \\
\hline & $(0.041)$ & $(0.044)$ & $(0.025)$ & $(0.101)$ & $(0.093)$ \\
\hline \multirow[t]{2}{*}{$\begin{array}{l}\text { Ln industry value } \\
\text { added }\end{array}$} & -0.002 & -0.038 & 0.024 & -0.076 & 0.059 \\
\hline & $(0.042)$ & $(0.044)$ & $(0.050)$ & $(0.252)$ & $(0.083)$ \\
\hline \multirow[t]{2}{*}{$\begin{array}{l}\text { Ln population } \\
\text { density }\end{array}$} & 0.430 & $0.517^{*}$ & 0.265 & 0.518 & $1.010^{*}$ \\
\hline & $(0.273)$ & $(0.305)$ & $(0.204)$ & $(0.855)$ & $(0.551)$ \\
\hline \multirow[t]{2}{*}{ Ln urbanisation } & $0.388^{* *}$ & 0.099 & -0.213 & $-1.609^{* *}$ & -0.169 \\
\hline & $(0.173)$ & $(0.176)$ & $(0.157)$ & $(0.681)$ & $(0.326)$ \\
\hline \multirow[t]{2}{*}{ Ln energy use } & $0.741^{* * *}$ & & 0.002 & 0.069 & 0.144 \\
\hline & $(0.074)$ & & $(0.037)$ & $(0.148)$ & $(0.141)$ \\
\hline \multirow[t]{2}{*}{ Ln trade } & $0.087^{* * *}$ & $0.078^{* *}$ & -0.038 & 0.018 & -0.078 \\
\hline & $(0.030)$ & $(0.031)$ & $(0.025)$ & $(0.099)$ & $(0.056)$ \\
\hline \multirow[t]{2}{*}{$\begin{array}{l}\text { Ln Control of } \\
\text { corruption }\end{array}$} & $-0.099^{* * *}$ & $-0.113^{* * *}$ & -0.016 & $-0.438^{* * *}$ & $0.104^{*}$ \\
\hline & $(0.033)$ & $(0.033)$ & $(0.029)$ & $(0.122)$ & $(0.059)$ \\
\hline \multirow[t]{2}{*}{ Ln Political stability } & $0.114^{* * *}$ & $0.127^{* * *}$ & -0.026 & $-0.305^{* *}$ & $-0.123^{*}$ \\
\hline & $(0.037)$ & $(0.037)$ & $(0.032)$ & $(0.127)$ & $(0.068)$ \\
\hline \multirow[t]{2}{*}{$\begin{array}{l}\text { Ln Voice \& } \\
\text { accountability }\end{array}$} & $0.091^{* * *}$ & $0.089^{* *}$ & 0.020 & 0.072 & 0.044 \\
\hline & $(0.034)$ & $(0.035)$ & $(0.023)$ & $(0.090)$ & $(0.065)$ \\
\hline \multirow[t]{2}{*}{$\begin{array}{l}\text { Ln Government } \\
\text { Effectiveness }\end{array}$} & 0.072 & 0.082 & $-0.114^{*}$ & -0.421 & -0.305 \\
\hline & $(0.106)$ & $(0.109)$ & $(0.060)$ & $(0.272)$ & $(0.215)$ \\
\hline Sample size & 882 & 882 & 278 & 255 & 690 \\
\hline Hanson-j stat & 5.522 & 6.459 & 0.743 & 4.200 & 2.206 \\
\hline P-value & 0.063 & 0.039 & 0.690 & 0.122 & 0.332 \\
\hline Anderson & 26.63 & 27.32 & 40.15 & 31.86 & 16.82 \\
\hline P-value & $(0.000)$ & $(0.000)$ & $(0.000)$ & $(0.000)$ & $(0.000)$ \\
\hline $\begin{array}{l}\text { Cragg Donald F- } \\
\text { stats }\end{array}$ & 8.784 & 9.028 & 13.35 & 10.38 & 5.495 \\
\hline
\end{tabular}

Standard errors in parentheses, ${ }^{*} p<0.10,{ }^{* *} p<0.05,{ }^{* * *} p<0.01$ 
Table A3: Fixed effect regression results for informal and governance models

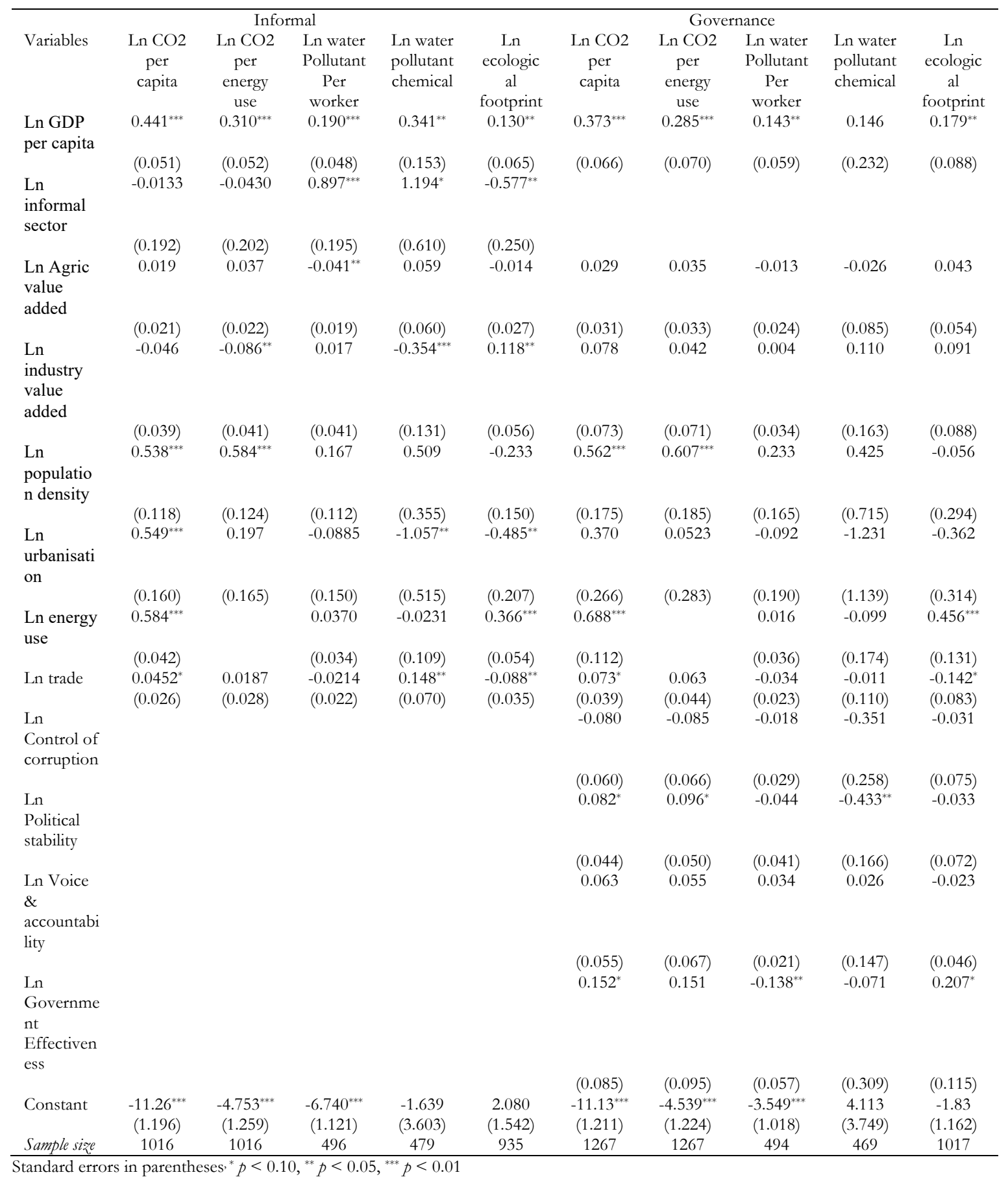


Table A4: IV-GMM- FE regression results for a new informal sector index (informal2)

\begin{tabular}{|c|c|c|c|c|c|}
\hline & $\begin{array}{l}\mathrm{Ln} \mathrm{CO}_{2} \text { per } \\
\text { capita }\end{array}$ & $\begin{array}{l}\mathrm{Ln} \mathrm{CO}_{2} \text { per } \\
\text { energy use }\end{array}$ & $\begin{array}{l}\text { Ln water } \\
\text { Pollutant } \\
\text { Per worker }\end{array}$ & $\begin{array}{l}\text { Ln water } \\
\text { pollutant } \\
\text { chemical }\end{array}$ & $\begin{array}{c}\text { Ln ecological } \\
\text { footprint }\end{array}$ \\
\hline \multirow[t]{2}{*}{ Ln GDP per capita } & 0.194 & 0.0839 & 0.0249 & 0.352 & $0.690^{* * *}$ \\
\hline & $(0.120)$ & $(0.111)$ & $(0.0788)$ & $(0.287)$ & $(0.191)$ \\
\hline \multirow[t]{2}{*}{ Ln informal2 } & $0.0390^{*}$ & $0.0417^{*}$ & $-0.0398^{* *}$ & $-0.138^{* *}$ & 0.0163 \\
\hline & $(0.0217)$ & $(0.0222)$ & $(0.0157)$ & $(0.0555)$ & $(0.0342)$ \\
\hline \multirow{2}{*}{$\begin{array}{l}\text { Ln Agric value } \\
\text { added }\end{array}$} & -0.0269 & -0.0248 & -0.0337 & -0.0141 & $0.0760^{* *}$ \\
\hline & $(0.0242)$ & $(0.0251)$ & $(0.0204)$ & $(0.0688)$ & $(0.0386)$ \\
\hline \multirow{2}{*}{$\begin{array}{l}\text { Ln industry value } \\
\text { added }\end{array}$} & 0.0420 & 0.00939 & 0.0341 & -0.197 & 0.0391 \\
\hline & $(0.0379)$ & $(0.0400)$ & $(0.0409)$ & $(0.160)$ & $(0.0611)$ \\
\hline \multirow{2}{*}{$\begin{array}{l}\text { Ln population } \\
\text { density }\end{array}$} & $0.385^{* * *}$ & $0.417^{* * *}$ & 0.0306 & 0.469 & 0.241 \\
\hline & $(0.131)$ & $(0.138)$ & $(0.128)$ & $(0.438)$ & $(0.203)$ \\
\hline \multirow[t]{2}{*}{ Ln urbanisation } & $0.511^{* * *}$ & 0.238 & -0.104 & $-0.933^{*}$ & -0.282 \\
\hline & $(0.149)$ & $(0.149)$ & $(0.144)$ & $(0.526)$ & $(0.237)$ \\
\hline \multirow[t]{2}{*}{ Ln energy use } & $0.731^{* * *}$ & & 0.0358 & 0.0124 & $0.241^{* * *}$ \\
\hline & $(0.0529)$ & & $(0.0367)$ & $(0.126)$ & $(0.0814)$ \\
\hline \multirow[t]{2}{*}{ Ln trade } & $0.0729^{* * *}$ & $0.0630^{* *}$ & -0.0258 & 0.0976 & -0.0596 \\
\hline & $(0.0259)$ & $(0.0266)$ & $(0.0232)$ & $(0.0785)$ & $(0.0402)$ \\
\hline Sample size & 1139 & 1139 & 441 & 418 & 910 \\
\hline Hanson-j stat & 6.870 & 6.145 & 1.534 & 4.323 & 5.006 \\
\hline P-value & 0.0322 & 0.0463 & 0.464 & 0.115 & 0.0818 \\
\hline Anderson & 108.2 & 127.7 & 110.2 & 88.75 & 85.68 \\
\hline P-value & 0.000 & 0.000 & 0.000 & 0.000 & 0.000 \\
\hline $\begin{array}{l}\text { Cragg Donald F- } \\
\text { stats }\end{array}$ & 37.43 & 44.65 & 40.81 & 32.02 & 29.52 \\
\hline
\end{tabular}

Standard errors in parentheses, ${ }^{*} p<0.10,{ }^{* *} p<0.05,{ }^{* * *} p<0.01$ 